\title{
Care in a Time of Austerity: the Electronic Monitoring of Homecare Workers' Time
}

\author{
L.J.B Hayes* and Sian Moore
}

\begin{abstract}
Austerity places intense pressures on labour costs in paid care. In the UK, electronic monitoring technology has been introduced to record (and materially reduce) the working time and wages of homecare workers. Based on empirical findings, we show that, in a 'time of austerity', care is reductively constructed as a consumption of time. Service users are constructed as needy, greedy, time-consumers and homecare workers as resource-wasting time-takers. We point to austerity as a temporal ideology aimed at persuading populations that individual deprivation in the present moment, self-sacrifice and the suppression of personal need in the here and now is a necessary requirement to underpin a more secure national future. Accordingly, women in low-waged care work are required to eschew a rightsbearing, present-tense identity and are assumed willing to suppress their entitlements to lawful wages as a sacrifice to the future. By transforming our understandings of 'care' into those of 'time consumption', and by emphasizing the virtue of present-tense deprivation, a politics of austerity appears to justify time-monitoring in care provision and the rationing of homecare workers' pay.
\end{abstract}

Keywords: austerity, working time, care work, unpaid labour, minimum wage law

\section{Introduction}

Concerns about the labour-market undervaluing of care work are longstanding (Baines, 2004; England et al., 2002; Graham, 1991; Himmelweit, 2007; Mundlak, 2012; Rubery and Grimshaw, 2007). However, there has been little examination of the specific organizational mechanisms through which the value of paid care work is undermined (Palmer and Eveline, 2012). Since 2010, the UK government has implemented an austerity programme that has severely reduced state spending on public services. In this context, employers in the homecare sector have introduced telephone-based technology to monitor working time and support local-authority commissioning of home care from (mainly) private-sector providers (Bessa et al., 2013; Rubery et al., 2011; UK Homecare Association, UKHCA, 2012). Our study is the first to consider how homecare workers experience this electronic monitoring and is based on in-depth interviews with female homecare workers in two neighbouring localauthority areas in the south-west of England. It is both timely and distinctive because we position and understand paid care work within an economic, cultural and political landscape of austerity.

In this article we demonstrate how electronic monitoring reduces the wages of homecare workers and contributes to an industry-wide problem of non-compliance with UK national minimum wage law (National Audit Office, 2016). Our analysis engages with the neoliberal

Address for correspondence: *L.J.B. Hayes, Cardiff University; e-mail:hayesL@ cardiff.ac.uk 
austerity narrative of financial and moral compensation for public-sector excess in the period preceding the 2008 financial crash (Pearson and Elson, 2015; Potter and Westall, 2013). We suggest that an impact of austerity is to reduce the rights-bearing capacity and legal entitlements of low-waged women in homecare work. Accordingly, electronic monitoring is far more than the recording of working time. It is a 'technology relation' (Cockburn and Ormrod, 1993, p. 154) that redefines homecare workers' labour in quantitative and qualitative terms and undermines the labour-market value of paid care work.

In the UK, over 95 per cent of 'hands-on' care workers are women and home care is a poorly paid and highly gender-segregated occupation (Carroll et al., 2009; Eborall, 2010; Hussein and Manthorpe, 2014). Homecare workers give personal care to older and disabled people: visiting them in their own homes to provide assistance with washing, dressing, continence/incontinence and basic nursing care. State funding accounts for about 80 per cent service volume of the entire UK homecare sector (Holmes, 2015). Wages are by far the largest component in the cost of home care (IPC Market Analysis Centre, 2012) and as a rule of thumb the price of services purchased from the private sector is half the average cost of public-sector homecare provision (UK Homecare Association, UKHCA, 2010). Local authorities have a huge influence over, and legal responsibility for, the efficient and effective functioning of the homecare market in their respective geographic areas (see Care Act 2014, s.5). They also exercise a high degree of control over the price of home care: whether services are commissioned by local-authority officers on behalf of service users, or are bought in directly by service users in receipt of direct payments issued from the local authority (Atkinson and Lucas, 2013; Laing, 2014).

In the context of austerity, commissioning local authorities increasingly requires employers to use electronic monitoring technology to capture real-time data about the start and end times of homecare visits (IPC Market Analysis Centre, 2012). It appears that local authorities regard electronic monitoring as a remedy for the negative consequences of cuts to their budgets, as well as for concerns about care quality (in the sense of wanting assurance that visits to older and disabled people are actually made by the organizations with which they contract). A social tendency to believe in technology as a panacea for all problems, even social ones, is longstanding (Weinberg, 1966). Yet technology is always adopted within the context of existing, gendered, norms or values and raises significant questions of social equality; who benefits, who suffers, who accumulates, who accommodates? (See Bush, 2009.)

In England alone, the pay of hundreds of thousands of private-sector homecare workers is so low as to be unlawful according to national minimum-wage law (Gardiner, 2015; Public Accounts Committee, 2014). There have been repeated calls for local authorities to attend to their commissioning practices in relation to minimum labour standards (Equality and Human Rights Commission, 2011; House of Commons Scottish Affairs Committee, 2014; Low Pay Commission, 2013). Nevertheless, government intervention has been slow to materialize and the most recent statutory guidance falls short of imposing a requirement that local authorities ensure the pay of homecare workers employed by contracting organizations meets legal minimum standards (Department of Health, 2016).

Despite poor terms and conditions, the UK's homecare workforce is growing rapidly. Since the financial crash, social care has become a main source of women's low-waged employment and it is estimated that the care-at-home workforce will double in size across the UK within a decade, providing approximately 2 million jobs (Centre for Workforce 
Intelligence, CFWI, 2013; Fenton, 2013; Wittenberg et al., 2011). Unless funding for adult social care is increased, intense pressure on labour costs is likely to remain (Atkinson and Lucas, 2013; Kingsmill, 2014; Koehler, 2014).

Recent literature has explored recruitment and retention issues in the homecare industry, problems of national minimum wage non-compliance and the widespread use of zero-hours contracts (Bessa et al., 2013; Hayes, 2015; Rubery et al., 2011). We build on a growing literature focused on the management of working time in homecare (Bolton and Wibberley, 2014; IPC Market Analysis Centre, 2012; Pennycook et al., 2013; Rubery et al., 2015; UNISON, 2012). We find that although electronic monitoring works alongside zero-hours contracting in the homecare industry, zero-hours contracts are not a necessary condition of electronic monitoring. As organizational strategies, both may be co-implicated in the devaluing of caring labour but they are also distinguishable. While zero-hours contracts attempt to informalize obligations to provide or undertake work, electronic monitoring formalizes a disjunction between paid time and working time.

We develop an account of austerity in relation to social care and draw attention to ways in which particular understandings of time are produced and promoted through the application of electronic monitoring technology. Time is the inseparable backdrop against which care takes place. Under conditions of austerity, homecare services are reconfigured and care itself is reductively constructed as a consumption of time, service users are constructed as needy (or greedy) time-consumers and homecare workers as resource-wasting time-takers. We point to austerity as a temporal ideology aimed at persuading populations that individual deprivation in the present moment, self-sacrifice and the suppression of personal need in the here and now is a necessary requirement to underpin a more secure national future. By transforming our understandings of 'care' into those of 'time consumption', and by emphasizing the virtue of present-tense deprivation, a politics of austerity appears to justify time-monitoring in care provision and the rationing of homecare workers' pay. However, the resultant deprivation is not straightforwardly economic. It dovetails with matters of legal standing since austerity requires homecare workers to eschew a rights-bearing, present-tense identity and accept the denial of the right to be paid fully in accordance with minimum-wage law as a sacrifice to the future. In the face of ongoing budgetary pressures, electronic monitoring promotes the acquiescence of homecare workers by embedding organizational behaviours and giving rise to individual work routines that purport to rationalize service provision and certainly reduce service costs.

Electronic monitoring is a technological driver for very real degradations of employment and pay. It has introduced fundamental changes to the basis upon which homecare workers are employed, their capacity to deliver care and their expectation of an entitlement to receive pay for doing so. We draw attention to ways in which electronic monitoring recasts understandings of 'care' in relation to 'time' (Harrington, 2012) and suggest that the electronic monitoring of homecare workers' labour represents the rationing of social care in a 'time of austerity'.

\section{Austerity, gender and social care}

Although gender has proven to be a remarkably persistent site of inequality, it is also evident that over time, welfare states have delivered a quantifiable reduction in social inequality and practical support for women to engage in paid work (Taylor-Gooby, 2009). Yet as a consequence of austerity, much of the social infrastructure that promoted women's effective 
participation, as well as their access to legal protections at work, is under threat (Rubery, 2015; Theodoropoulou and Watt, 2011; Walby, 2009, 2012). EU populations are required to attend to individualist and market-led models of citizenship that emphasize self-reliance and relegate the recognition of human dependencies to the contingencies of interpersonal relations (Cameron, 2009; Finlayson, 2010; Taylor-Gooby, 2009). A politics of austerity thus hinges upon gendered assumptions about the capacity of families to provide care, welfare and support on the basis of kinship; as well as on the harnessing of women's unpaid labour within a domestic or community context.

Across the EU, states have begun to withdraw from prior political commitments to meet welfare needs collectively as a state function (Taylor-Gooby and Stoker, 2011). This has coincided with an increasingly confident articulation of social policy in neoliberal terms that enables the state to drive the development of markets in welfare, health and care provision, and seeks to harness economic competition and market forces in support of a rationing of entitlement (Levitas, 2012; Walby, 2009, 2012). Austerity demands that prior political commitments to social support, as a collective function of the welfare state, are claimed to be no longer affordable (Clarke and Newman, 2012). Austerity has been characterized as a process of ideological shift from questions centred on the financial industry to a political project intent on placing blame elsewhere (Allen and Taylor, 2012; Clarke and Newman, 2012).

The erasure of the idea that the severity of the global economic crash was exacerbated by systemic uncertainty (based on a widespread consensus of economists) has permitted an austerity response in which vast swathes of people are denied the stability and certainty that accompanied notions of state support and welfare (Corsetti, 2012). In the UK, national assistance laws in place since the welfare state was founded have been repealed and replaced by new legal principles based on 'wellbeing' and 'prevention' that individualize care needs as a matter of social and economic privacy (see Care Act, 2014, s.1; Hayes, 2017). Local authority duties to meet care needs are being consequently recast as undertakings to do the minimum necessary and eligibility for state support is reengineered so as to apply only to those for whom barriers to achieving wellbeing 'can and can only' be overcome by the intervention of a local authority (Clements, 2015; for example see Welsh Government, 2015, part 4). An intensification in the rationing of adult social care suggests that the work of caring is being increasingly pushed into the private, unpaid and unregulated realm of the family. However, there are also considerable impacts on the paid care workforce (Fernandez et al., 2014; Lethbridge, 2011). Austerity in the UK has intensified a preexisting and wellestablished neoliberal obsession with the transfer of public provision into private-sector markets and it has amplified the gendered impact of this shift (Allen and Taylor, 2012; Fawcett Society, 2012; Walby, 2015). Hence, whether care is paid or unpaid, it is frequently women who fill the gaps left by the retrenchment of the state (Duffy et al., 2013; Fawcett Society, 2013).

Both in its formal manifestations and in families, care is the foundation of the state's human infrastructure (Boydston, 1990; Glenn, 1992, 2010; Kessler-Harris, 1982). In respect of elder care, the austerity approach would seem especially complex. For several decades the populations of member states across the EU have seen falling birth rates and rising life expectancy. The meeting of elder care needs is a pressing issue with which EU member states must engage (Duffy et al., 2013; England and Folbre, 1999; Lethbridge, 2011; Taylor-Gooby et al., 2015) and depends in part on their ability to organize social care as a major site of paid employment (Carers UK, 2012; Lethbridge, 2011; Novitz and Syrpis, 2015). 
However, the very existence of an ageing population is recurrently constructed as an intractable social problem (Hansard, 2013; Langan, 1990; Pierson, 2002; Stone and Weiner, 2001). Care for the elderly is conceptualized as a bottomless pit of need and expenditure that threatens to precipitate ongoing economic crisis (Carers UK, 2012; Mullan, 2000; Rasmussen, 2004). Indeed, in the UK political attention to the care of older people is overtly driven by a desire to contain or reduce demands on the public purse (Dilnot Commission, 2011). Elder care is presented as if synonymous with accounts of 'financial crisis' (see the 'Good Care Costs Less' speech by Health Minister Jeremy Hunt, October 2014; Commission on Public Service Governance and Delivery, 2014, paras 1.31-41). These conflated sites of 'crisis' - the ageing population, and the financial crash of 2007-08 - appear alongside each other in a dynamic and shifting narrative about the need for public spending cuts (see, for example, Corsetti, 2012; Wallace et al., 2013). The spectre of a care 'crisis' at the heart of an ongoing financial 'crisis' is thus one aspect of a wider political project: tackling a perceived societal problem of state-supported human dependency (Taylor-Gooby and Stoker, 2011). The notion of domestic caregiving as a source of formal, paid employment is systemically undermined by the discursive coincidence of care with economic crisis as well as by the state's desire to (re)orientate political recognition of human dependencies from being public to private concerns. Implications for increased gender inequality arise from 'the association of care with the feminine, and therefore the subordinate, [which] is both a statement about the values of a society and the demographic profile of those who perform paid and unpaid care' (Duffy et al., 2013, p. 148).

\section{Care work as time work and the rise of electronic monitoring}

The preceding discussion has introduced 'austerity' as a multifaceted term: it straddles many fields in economic, political, legal and cultural forms (Centre for Local Economic Strategies, CLES, 2014; Evans, 2012; Latimer, 2013; Oxfam Case Study, 2013; Potter and Westall, 2013; Taylor-Gooby, 2009; Wynn, 2013). However, austerity is also a 'time orientation' that produces or promotes particular understandings of time (Nuttin, 1985). Heather Latimer argues that austerity is 'future orientated' in the sense that it focuses its justification for the harsh treatment of particular social groups on preserving the 'good life' for future generations. Accordingly, austerity exhibits a generational temporality that anticipates the future, as it takes effect in the present (Brammall, 2013; Latimer, 2013). This orientation supports a discourse in which 'good' citizenship is expressed as an individual sustainability of the self that is future-focused, in place of a prior emphasis on citizenship and individual rights that might be secured in the present moment (see Lonergan, 2015).

Discourses of austerity represent the ideological (re)generation of new and old gender regimes as values of worth and worthlessness are assigned to particular social communities (Latimer, 2013). Perceptions of generational division are used to justify an accelerated rollback of the welfare state and this is perhaps exemplified in the UK government's decision to rule out meeting the future additional costs of care for older people through general taxation on grounds that it would unfairly place 'a heavy burden on people of working age' (HM Government, 2009, p. 18). Contrast this with the emblematic 'cradle to grave' foundations of the British welfare state, which expressed the commonality of ageing as a shared journey in common time (see Schües, 2011). This appeal to the homogeneity of human experience stands in sharp contrast to austerity's appeal to self-reliance among ageing 'individuals' who are living longer and are required to manage the consequences of their own over-consumption of (life)time. 
Concerns about the inadequacy of public spending on adult social care predate the UK's austerity programme (Fernandez et al., 2014). However, adult social care is the largest category of local-authority expenditure and a principle casualty of austerity (Centre for Local Economic Strategies, CLES, 2014; Fernandez et al., 2014; National Audit Office, 2014). Between 2010 and 2014, local authorities absorbed an effective 26 per cent cut in funding and have consequently redoubled their efforts to purchase care from private-sector contractors at ever-lower prices (Association of Directors of Adult Social Services, ADASS, 2015; Public Accounts Committee, 2014). The imposition of tighter eligibility thresholds means that about a third of elderly people who would previously have been eligible are now unentitled to state-funded care (Age UK, 2015; Fernandez et al., 2014). It has been estimated that a million elderly individuals are left to struggle alone with tasks that are fundamental to their day-to-day existence (Triggle, 2015). The shift of the homecare workforce over two decades from the public to the private sector has effectively removed this large cohort of lowwaged women from access to legal protection against discriminatory pay setting, as well as from the benefits of provisions set out in collective agreements covering public-sector workers that included occupational pensions and (what are now considered) generous sick pay and holiday entitlements (Hayes, 2014; Lewis and West, 2014; Thornley, 2006). Across the UK, an overwhelming majority of homecare jobs are with private-sector employers and most homecare workers are employed by care companies, although direct-hire arrangements between workers and service users are facilitated where local authorities provide 'direct payments' to enable service users (or their family/representatives) to arrange care themselves (Fenton, 2013; Hasler and Marshall, 2013; Hayes, 2017).

Several studies have connected employment insecurity and low wages in homecare with the use of zero-hours employment contracts (Bessa et al., 2013; Kingsmill, 2014; Koehler, 2014; Rubery and Urwin, 2011). This form of contracting is now standard within the industry (Gardiner, 2014) and it means that there is no legal obligation between employers and workers to provide or perform work (Adams and Deakin, 2014). Zero-hour contracting reflects employer preference for work-on-demand scheduling (Jacobs and Padavic, 2015). Under these arrangements, staff bear the risk of a loss of work or pay when a service user is admitted to hospital or a care home. Zero-hour contracts make it easier for employers to insist on irregular working hours, resulting in episodic and unpredictable working time, while staff tend not to be paid for time spent travelling between clients (Rubery et al., 2011). Indeed, zero-hour contracts are a key mechanism through which 'unproductive' time is managed out of the labour process, with paid and unpaid working time blurred since homecare workers are required to be constantly available to their employers and have to wait around in periods between visits. Accordingly, home care is discursively constructed as an industry in which there is 'not enough time to care'; it would seem that austerity is producing new narratives about temporal deficit in home care (see Bolton and Wibberley, 2014; UNISON, 2012).

The marketization of care is a reductive process that strives to conceive of care as a commodity for capitalist exchange. Yet, as previous UK studies of homecare work have evidenced, formal organizational strategies seeking efficiency and profit in the context of care-contracting fail to capture the relational complexities of homecare work (Bolton and Wibberley, 2014; Rubery et al., 2015). Homecare work is an embodied practice that requires mental and physical patience (England, 2005). It is not set in a free-floating 'timelessness', but demands an appreciation of the changing and adaptive human body. It is in the relational connection between caregiver and care receiver that home care is 'co-produced' (Needham and Carr, 2009) and hence homecare workers must exhibit an interactive capacity to wait for direction or response. These values of patience, change and waiting (Stoller, 2011) point to 
the temporal dimensions of home care. The labour of homecare workers is experienced by service users as 'time' in the sense of their appreciation of homecare worker presence (see Edebalk et al., 1995; Eustis and Fischer, 1991; Francis and Netten, 2004). Homecare workers invest in relationships with service users that require that they have time to 'be with' another person; to be curious about them and develop solidarity with them (Cameron and Moss, 2007). 'Time' is the inseparable backdrop against which 'care' takes place. This is not to say that the only experience of homecare service users is the experience of presence, nor that home care is the gift of time, but rather that 'time' and 'care' are inseparable conceptual domains.

Electronic monitoring technology has increased the capacity for local authorities and care companies to extract unpaid labour from homecare workers by targeting the organization of their working time. Homecare workers are required to use landline telephones or GPS mobile telephone systems to register the minutes they spend inside each service user's home and it is on the basis of these minutes that the homecare worker is paid. Since the local authority is paying only for contact time (rather than paying a set price for the preprogrammed length of the visit it has commissioned), the cost savings are sizable. For example, by requiring homecare providers to operate electronic monitoring systems, Hampshire County Council saved in excess of $£ 1$ million in 2013-14 (CM2000, 2014). Devon County Council and South Gloucestershire similarly reported savings equivalent to 10 per cent of their entire purchasing budgets for adult social care by paying only for 'actual' care delivered. The collecting of realtime data about homecare workers' whereabouts and visit durations enables invoices to be generated automatically between their employer organization and the commissioning local authority. Fees are paid on the basis of this contact time only and the employer remains responsible for the full costs of service delivery (which includes the cost of homecare workers' time associated with training, supervision, team meetings, sickness, holidays and missed calls due to service users' arrangements or hospitalization). The labour cost of noncontact time, however, is effectively erased because it is constructed as unpaid working time in the context of downward pressure on local-authority care budgets. From a managerial perspective, electronic monitoring is discursively constructed as a means to 'enhance [care worker] performance' in order to deliver services at the rates required by local authorities (for example see person specification/job description, Renaissance Personnel, 2016). However, the logic is to save money by reducing the proportion of homecare workers' time that is paid time, and to intensify labour (IPC Market Analysis Centre, 2012). The narratives of the homecare workers we interviewed substantiate this argument.

\section{Methodology}

Care workers' views are largely absent from research about social care (Eaton, 2000; Hayes, 2017). However, we are aware of two prior empirical studies that have produced insights about the use of electronic monitoring. Brown and Korczynski's study (2010) of an electronic monitoring pilot scheme in public-sector homecare services found that it intensified labour but did not reduce the discretionary effort of workers. In contrast to our study, results were ascertained through the use of workplace surveys by a directly employed local-authority workforce for whom pay and hours of work were assured irrespective of electronic monitoring.

The Department of Health commissioned Rubery et al. (2011) to embark upon a comprehensive mixed-methods study of recruitment and retention in the social-care workforce (including day care, residential care and homecare provision across the public and 
private sector, 2007-10). Although the research did not focus on electronic monitoring, its final report noted that if electronic monitoring was to become widespread in home care it might reduce pay by 'restricting paid work time, to time actually spent in people's houses' (Rubery et al., 2011, p. 4). A more recently published examination of working time based on data from the same study characterized HR practices as relying on the 'goodwill' of homecare workers to work more hours than those for which they are paid (Rubery et al., 2015; see also Bolton and Wibberley, 2014).

Our research was funded through a British Academy/Leverhulme small grant. We sought to explore the impact of electronic monitoring on wages, hours and the employment experiences of women working in home care in one city in the south-west of England. We considered that participation in this research might expose our participants to unfavourable treatment at work and hence chose not to recruit through employer contacts. The focus was on the private sector, where union membership is very low; hence we did not engage homecare workers through trade-union routes. Rather, we used social media to promote our research and additionally recruited participants through local networks. Following initial expressions of interest from potential participants we conducted a telephone discussion with each of them to ascertain their eligibility for inclusion in the study.

In the summer of 2014, we conducted in-depth interviews with 14 homecare workers about their recent experience of electronic monitoring. Nine of our participants were currently working for private-sector care companies (each had a different employer); six of these participants worked on the basis of a zero-hours contract, three did not (they had a contract that provided a minimum guarantee of paid hours of work). A further five participants had recently left their employment with care companies and were now working under direct-hire arrangements as personal assistants to older and disabled people. Despite a tendency to change their jobs between one care provider and another, all participants were committed to continue working in the care sector and felt a strong sense of professional commitment to the older and disabled people with whom they worked. Interviews lasted up to 3 hours and all but two took place in participants' own homes. Therefore, the levels of information disclosure may have been higher than if the interviews had taken place in a more formal setting. Each homecare worker gave written consent for the data to be published. All data has been anonymized and pseudonyms used.

We triangulated our data through analysis of documentary evidence from two neighbouring local authorities responsible for commissioning homecare services and separate interviews with six local-authority officers: a senior manager for a leading provider of electronic monitoring software/systems; a senior manager at a disabled persons' independent living centre that offers support to care users in receipt of direct payments; and three employers. There are a total of 28 interviews with 25 participants. The data presented in the findings are drawn from the interviews with homecare workers.

\section{Findings}

Our interview data evidenced that homecare workers understood electronic monitoring as a system that limited their pay and, on the most favourable assessment, would allow their pay to correspond to the length of time they spent in a service user's home. Charlotte explained how electronic monitoring worked on a day-to-day basis. When she arrived at a service user's home, she would say 'hello' and then ask to use the landline telephone to ring a freephone service. She would use her own personal code to activate the automated answer-facility 
service (hosted by the electronic monitoring service provider). It would enquire of her, 'is this the start of the call or the end of the call?' and she would use the keypad to answer the question. According to Charlotte the purpose of the system was:

They can clock if you're five minutes late, a minute late or whatever. The same going out, they know exactly what time you leave. But you could leave dead on time but they don't give you any time for travelling. You can be stuck in traffic for twenty minutes, half an hour, but you don't get paid for that. And then they're questioning you why are you late? It's not a case of skiving off anywhere, you are stuck!

Charlotte talks about the electronic monitoring system as 'they' — a disembodied power that controls her, transcending her individual employer. 'They' check if her timekeeping matches minute by minute with her schedule; 'they' are aware of her leaving a call; 'they' are responsible for failing to pay for the time it takes her to get to the next appointment and 'they' regard her with suspicion and hold her to account. This (dis)identification points to the dimensions of the 'technology relation' in which many of the homecare workers situated themselves. When Charlotte was not 'clocked in', her work was not recognized as paid labour. The technology relation essentially determined when she was either visible or invisible for the purposes of controlling her movements and her pay.

Although electronic monitoring restricted earnings by anchoring paid time within service users' homes, differences arose between the intended contact time and the actual time for which homecare workers were paid. The unpredictability inherent in working both 'on the road' and 'in the home' meant that neither the visit times, nor the duration of visits, would necessarily match with official intentions. Hence, the idea that it was only 'travelling time' that was unpaid was not the full story. Unpaid labour also included large periods of time when calls overran, as well as time involved in meeting statutory requirements (such as attending induction or manual handling training) and maintaining good working relations (for example time in supervision or at team briefings).

The UK Homecare Association (the employers' representative body) has estimated that about 19 per cent of homecare workers' time is spent travelling (and hence is generally unpaid) (UK Homecare Association, UKHCA, 2015). However, our research participants typically regarded their 'working time' as the length of time for which they wore their uniform and on this measure, it was only about half of their working time that would qualify for pay under the electronic monitoring regime on a typical day. Shelley had been employed in a series of different homecare jobs under a variety of contractual arrangements and she explained, 'I can't think of any other job where you would actually be ready to work, keep your uniform on all day and only be paid for a few hours. It's just absolutely nutty, not enough for a wage to live from'. Her experience was of committing herself to work a 15-hour day, wearing her uniform for this length of time, yet receiving anywhere between 5 and 8 hours of pay in return.

Amongst our research participants, dissatisfaction with pay was not only felt deeply and widely; it was also directly attributed to electronic monitoring. The proportion of a working day that attracted pay appeared arbitrary to many homecare workers because electronic monitoring was necessarily inflexible, yet service users' care needs and personal requirements could change on an hour-by-hour or day-to-day basis. Many homecare workers were frustrated at a growing realization that they had little choice but to behave in ways that put the correct operation of the telephone system at the centre of their attention, ahead of 
what they believed should have been a primary concern for the quality of care services. The operation of the technology actually reduced homecare workers' autonomy and left them illequipped to deal with the demands of the job. As Kate, a homecare worker with many years' experience, explained, 'some people can spend half an hour on the loo, or they could have an accident where they mess themselves and you've got to stay there and clean them. You can't walk away'. Set within the technology relation, such integral and responsive aspects of caregiving were rendered problematic and placed workers under huge pressure in situations already charged with emotion. Inevitably, unforeseen circumstances required homecare workers to stay and deal with the situations in which they found themselves. However, under the electronic monitoring scheme there was no corresponding commitment that workers would be paid. Because of low pay, Tessa was considering leaving her current job and she described how management placed responsibility for her irregular earnings directly with the commissioning local authority:

They said to us, if we went over our time with a service user we wouldn't get paid because that's not the contracted hours. The council won't pay them, the agency, so the agency won't pay us. So if we did an extra hour, which happened quite often if somebody had a fall or someone wasn't well and you stay on because it's your duty of care, we wouldn't get paid for that.

Anne had been working for a homecare agency up until eight months ago, and now worked as a personal assistant. She recalled a time when a stairlift had broken down and she was faced with ameliorating the distress of both her service user suspended in the chair and the service user's husband, also a disabled person, who was stranded upstairs. She spent several hours trying to manage the situation until engineers arrived and yet 'didn't get paid for the hours of being there [but] you can't just walk out of the door and leave and say "well, my time is up now, I've got to go!"”.

Although a majority of the homecare workers in our study were engaged on the basis of zerohours arrangements, several had employment contracts that guaranteed a minimum number of paid hours, to be worked flexibly. However, these guaranteed-hours contracts did not provide for fixed hours of work. For example, Alison had a contractual guarantee of 37 hours of paid work each fortnight. She explained: 'obviously you don't get [paid] from the time of starting work to the time of finishing'. The pay guarantee essentially bound Alison to work for as long as it would take her to register at least 37 hours of homecare provision via the electronic monitoring system. In return, she would receive at least 37 hours of pay each fortnight. However, she had no control over the allocation of her work and she worked at the demand of her employer, on a flexible basis. Gaps in between visits, extra time when visits overran and her travelling time all remained unpaid. Even a well-organized work schedule could involve an hour and a half of unpaid 'hold ups' each day and Alison explained: 'over a week, that's nearly a whole day's pay that you are working for nothing'. Her guarantee of 37 hours was not a guarantee that fixed her working time. Rather, it provided her with the promise of a minimum income based on a minimum number of paid hours to be accumulated within an unknown number of working hours.

Cycles of over- and under-staffing were commonly experienced by our research participants. Even though Tessa had a contract that guaranteed her a minimum of 16 hours of pay each week, she was adversely affected when her employer took on new workers and competition for hours of paid work increased. She found that many of her regular calls would be assigned to new workers and she had to work for longer periods of time to fill up her 'guarantee' of 
16 hours' paid work. She was sent further afield, her travelling time increased and she had to work on her notional days off. Tessa said it felt like 'you were working for nothing, really not working for anything'.

Rita was a homecare worker who described electronic monitoring in derisory terms as, 'this system where we are on peanuts'. She perceived that electronic monitoring put her under intense pressure to meet externally driven time constraints that were simply unachievable. As a result, she lost pay. Employed on a zero-hours contract she was subject to electronic monitoring, and paid on a minute-by-minute basis. Visits that had been scheduled for 30 minutes could actually net her only 15 minutes of pay if she arrived late; and her late arrival was frequent. Rita's heart went out to 'the poor clients' who suffered when a call was too short, but the overriding imperative of working to the diktat of the electronic monitoring scheme meant she knew she had to leave on time to get to the next person.

On days when Rita's rota was crammed with more calls than could be properly serviced, the greater intensity of her work perversely resulted in her earning less. Each separate visit introduced new sources of potential unpaid time and she claimed her co-worker calculated that the introduction of electronic monitoring had resulted in a wage drop of $£ 50$ a week. Rita identified the different ways 'you're losing out' with each call, even when the job was going smoothly: waiting for colleagues to turn up to assist with a two-person task such as hoisting a heavy service user; not being able to clock in until family members had finished their own personal telephone calls; explaining to service users 'about ten times' why the telephone call was necessary and reassuring them it would not add to their telephone bill. Sometimes, the technology would fail. At other times, and particularly when she was in a hurry, Rita would simply forget to clock in, so she lost money that way. Both homecare workers and employers in our study identified that forgetting to $\log$ in or out was quite a common occurrence and could result in neither the worker nor the homecare provider being paid for the visit.

For Shelly, shifts were never guaranteed but her dissatisfaction with income irregularity went beyond the issue of zero-hours contracting. She reasoned, 'I really enjoy the work but it's just the clocking in system is awful'. If she arrived late for a call that was officially scheduled to last for 30 minutes, the fixed end point of pay for the visit would not be extended, meaning, 'you can only clock it in as quarter of an hour, but invariably it takes you longer than that'. Homecare workers considered that visits scheduled for 15 minutes were particularly exploitative because the increased volume of visits meant there was a greater concentration of visits that would overrun, and hence a greater proportion of their working time went unpaid (such short visits are used by 74 per cent of local authorities; see UNISON, 2016). Shelley tried not to leave care tasks unfinished and this meant she was always behind the clock and really struggled to make ends meet. She claimed that electronic monitoring limited the people who could 'survive' in a homecare job to those 'people who've got some other support financially because it's not viable to do it'.

Indeed, low pay meant that homecare workers who did not have partners in well-paid work were dependent on state benefits, particularly for housing costs. Karen's manager had explicitly told her that she was expected to rely on her husband to manage the unpredictability of her earnings. Tessa was under pressure from her partner to stop working because she didn't get paid for enough of her working time and consequently her employment was of marginal economic benefit to the family. Morag had been forced to borrow money from her children and other family members when her pay packet was so small that she didn't have enough for food and heating. 
Gillian resented being expected to treat service users like machines who would perform to cue when working for a homecare agency and had recently started working directly for an older person instead. She felt that under conditions of electronic monitoring she had been expected to think about service users like there was no need for 'human care' and 'be like, right come on Mrs so-and-so, we've got to get you in and get you washed, dressed ... put drugs in you, whip the hoover around quickly and then out again'. Her concerns were echoed by Donna, who said that the set times covered by electronic monitoring bore little relation to the actual performance of her work and 'we have to cut corners sometimes' like neglecting the washing up or failing to empty the bins. Her strong sense of commitment to her service users, however, meant she would often return to the same home later in the day to finish her duties, outside of the watch of the electronic monitoring system and consequently without pay. Other interviewees were either unwilling or unable to engage in such discretionary labour and expressed embarrassment at being pushed into situations of 'professional incompetence' when they were working in a hurry.

Homecare workers claimed that the intensification of labour imposed under electronic monitoring produced a greater proportion of unpaid time in their working lives and also increased the risk of error because 'people started rushing it ... mistakes happen'. The work of correcting these mistakes was another source of unpaid labour. Homecare worker Rita recalled an occasion when a service user had been given the wrong medication because an overstretched homecare worker 'forgot to concentrate'. Getting appropriate medical support, reassuring the service user and informing their family not only involved Rita in many hours of unpaid time, but it also meant that all her other calls for the day were allocated to someone else and she 'lost the work, through no fault of [my] own'.

\section{Discussion}

Our study highlights that the relationship between paid and unpaid working time determines earnings in home care and that the construction of 'care' as 'time consumption' connects homecare workers' wages to issues of care quality. Electronic monitoring rescripts what matters most; and what counts inside the homes of older people is conformity with predetermined and disembodied calculations of clock time. Hence, electronic monitoring is not merely a tool used to implement time-management practices and deliver budget cuts for local authorities; its collective significance is to reconfigure understandings of working time and of care.

Electronic monitoring purports to monitor care quality (in the sense of ensuring that visits are made), at the same time as it strips care of its interactive flexibility and attempts to deny the relational underpinnings of individual service. The exercise of caring skills and the quality of care provided are hidden from view. Electronic monitoring is a disembodied and allpervasive form of control that reduces the practice of care to the fulfilment of a series of tasks within a predetermined time period, which is often illusory. Bolton and Wibberley (2014) have suggested that home care is organized as a combination of formal and informal (often discretionary) labour. Our findings suggest that electronic monitoring explicitly demarcates formal from informal labour, removes social interaction and has the potential to undermine the discretionary labour that is noted in other studies as being a central feature of homecare work and the gendered relations that underpin it (Bolton and Wibberley, 2014; Rubery et al., 2015). 
All the participants in our study thought that they were underpaid; not on the basis of their hourly wage, but because they considered that the quantity of unpaid work now required of them was unjust and exposed them to considerable wage uncertainty. The reconfiguration of paid and unpaid working time under electronic monitoring appears to have made it clearer to homecare workers that a significant proportion of their labour is unpaid. In the 'unknowability' of the circumstances and events that will define each visit, homecare workers experience anxiety because the quantity of working time required for care-giving may not match the time formally made available as paid time. It suggests that electronic monitoring forces women into relations of economic dependence, because of low pay and unpredictable pay. Ironically, wage uncertainty coexists with the very clear demarcation between paid and unpaid time that electronic monitoring purportedly embeds.

Our findings have implications for the legal regulation of pay in the homecare sector, particularly in light of the current Conservative government's national minimum wage policy, which has introduced a higher rate 'national living wage' for workers aged 25 and over from April 2016. Although this policy has the potential to improve pay in low-wage industries, it does not address the problems that lie behind an established pattern of widespread noncompliance with national minimum wage law in the homecare sector (Bessa et al., 2013; Low Pay Commission, 2016; National Audit Office, 2016); fails to address gendered weaknesses in the statutory framework that facilitate unpaid working time (Hayes, 2015, 2017); and does not impose national minimum wage liabilities on local authorities for the wages of workers who deliver public services and are employed by contactor organizations. It would seem that while contractors and commissioning local authorities purport to cede control over paysetting to a technology, homecare workers are highly aware that commissioning local authorities require and orchestrate unpaid working time. Rubery and others have argued that social care policy-making overlooks the significance of employment relationships in home care and disregards expectations of contractual commitments and the enforcement of labour standards (Rubery and Urwin 2011; Rubery et al., 2012). Our findings additionally suggest that electronic monitoring exacerbates homecare workers' sense of subordination in the labour market through facilitating the explicit control of their paid working time by local authorities who are not their employers and do not carry legal responsibility for wages.

Zero-hours contracting and electronic monitoring are discrete strategies deployed in the homecare market. While zero-hours contracting dispenses with contractual commitments to provide regular work, it can blur the relationship between paid and unpaid labour by expecting workers to be available for work as and when they are required. Yet zero-hours contracts, on their own, do not necessarily require work without pay. An effect of electronic monitoring, however, is to empty the employment contract of its basic legal premise that wages will be provided in rational exchange for work undertaken. Electronic monitoring demarcates, in abstract, what is paid and what is unpaid. However, as the participants in our study explained, electronic monitoring shaped the haphazard way in which pay attached to working hours in practice.

\section{Conclusions}

A legacy of structural conditions and gendered norms, through which the caring labour of women has been disregarded and undervalued, continues to shape paid care work. By exploring electronic monitoring from the perspective of homecare workers, we can see that its introduction signals the degradation of work, intensification of labour and removal of autonomy over work. Although technology facilitates social change, it always 'enters the 
present culture, accepting and exacerbating the existing norms and values' in and through time (Bush, 2009, p. 119). In considering questions of social equality raised by the implementation of this technology we have argued that electronic monitoring gives expression to gendered hierarchy by constructing care as a temporal commodity in order to exercise economic control over women in domestic spaces. It enables the state, in the form of local authorities, to engage in third-party surveillance within the employment relation and to benefit from the consequent quantitative reduction of paid working time. Rubery and Rafferty (2013) predicted that austerity would have a disproportionate impact upon women, and that women would resist removal from the labour market. Our findings bear this out, but also point to very real reductions in pay and conditions for women working in this rapidly expanding sector.

Time is socially produced by practices that persuade that a specific timeframe should govern in a specific context (Eriksen, 2001; Gurvitch, 1963). Austerity has foregrounded specific representations of time that have been taken up and intertwined with the production of social care. The plausibility, and hence implementation, of electronic monitoring in home care hinges upon establishing that it is legitimate and justified to measure care in a time of austerity; and then to use that measuring to ration service provision and limit the extent to which homecare workers are paid for the care they provide. In our study, electronic monitoring was shown to reconstruct homecare provision by imposing a routine of clocking in and out that served to emphasize that time was rationed and externally adjudicated. It did not introduce regularity into care arrangements, did not advance rational nor realistic work scheduling, and seemed incapable of ensuring sustainable relationships between care workers and service users.

Electronic monitoring also exerts gendered and qualitative forms of control by producing care work as an unpaid activity. It represents a power to determine when workers may be rendered practically and economically invisible in the performance of their duties. This technological capacity to 'appear' or 'disappear' homecare workers is integral to the construction of care in a time of austerity. As a 'technological fix' for the underresourcing of social care, electronic monitoring communicates political suspicions that public monies may be wasted in paying for care and hence stringent controls and rationing can be ostensibly justified. This speaks to the austerity project of erasing recognition of human dependency as anything other than a private concern; to gendered expectations of women's propensity to give care without pay; and it reinforces the perceived inefficiency of 'problematic' aged or disabled bodies. Such an influence strengthens the ability of corporations to accumulate economic benefit from the commodification of care in a time of austerity and does so by (re)turning to powerful associations that connect paid employment and legal entitlements with the protection of male interests.

In a time of austerity, both services users and homecare workers are expected to accommodate the consequences of underfunding. Griffin (2015) has claimed that austerity discourses appropriate women's purported tendencies to behave responsibly and iron out dayto-day problems as a form of crisis management to which women are 'naturally' suited. Our study suggests that, situated within the technology relation of electronic monitoring, homecare workers bear emotional, physical and economic responsibility for the failure of care systems to deliver adequate care services. They are required to fill gaps in care provision that arise in the wake of retrenchment by the state. Electronic monitoring itself is a 'time perspective' (Nuttin, 1985, p. 16) in the sense that it structures and specifies the behavioural acts we label 'care' and quantifies them as 'time consumption'. Thus contests over the 
appropriate adoption of legally or managerially instituted notions such as 'travel time', 'clock time' or 'working time' are also struggles to assert the legitimacy of subjective notions such as 'time to care'.

We agree with Harrington (2012) that 'struggles over time ... are also commonly struggles over basic ethical and political values (p. 5). Electronic monitoring appears to be ostensibly justified on the basis that a 'crisis' of underfunding in adult social care can be controlled by enforcing stringent controls on the labour cost of the homecare workforce. Its focus on effectively punishing homecare workers for late arrivals by reducing their pay shifts blame for the practical effects of under-resourcing onto their shoulders as individuals. Electronic monitoring also undermines the ability of homecare workers to concentrate on the provision of care in the psychological present. They are constrained in anticipation of future need (in the shape of concerns about the timing and requirements of their next visit, as well as by an intensification in service rationing, short visit times and their experience of low and irregular wages). Under systems of electronic monitoring, a lack of regard for homecare workers as the bearers of employment rights, and an emphasis on their moral and social responsibilities as 'good citizens, is brought sharply into focus by the highly gendered requirement that an increasing proportion of their working time is provided without pay. In a time of austerity, their individual expectations of a right to be paid on the basis of their actual labour are disappeared from view.

\section{Declaration of conflicting interests}

The authors declared no potential conflicts of interests with respect to the authorship and/or publication of this article.

\section{Funding}

The empirical work upon which this article is based was funded by a Leverhulme / British Academy Small Grant Award.

\section{References}

- Adams, Z. and Deakin, S. (2014) Re-regulating Zero-hours Contracts. London: Institute of Employment Rights.

- Age UK (2015) Later Life in the UK. London: Age UK.

- Allen, K. and Taylor, Y. (2012) Placing parenting, locating unrest: failed femininities, troubled mothers and riotous subjects. Studies in the Maternal, 4,2, 1-25.

- Association of Directors of Adult Social Services (ADASS) (2015) Budget Survey 2015. London: Association of Directors of Adult Social Services.

- Atkinson, C. and Lucas, R. (2013) Policy and gender in adult social care work. Public Administration, 91,1, 159-173.

- Baines, D. (2004) Caring for nothing: work organization and unwaged labour in social services. Work, Employment and Society, 18,2, 267-295.

- Bessa, I., Forde, C. and Moore, S. (2013) The National Minimum Wage, Earnings and Hours in the Domiciliary Care Sector. London: Low Pay Commission.

- Bolton, S.C. and Wibberley, G. (2014) Domiciliary care: the formal and informal labour process. Sociology, 48,4, 682-697. 
- Boydston, J. (1990) Home and Work: Housework, Wages, and the Ideology of Labor in the Early Republic. New York: Oxford University Press.

- Brammall, R. (2013) The Cultural Politics of Austerity: Past and Present in Austere Times. Basingstoke: Palgrave Macmillan.

- Brown, K. and Korczynski, M. (2010) When caring and surveillance technology meet: organizational commitment and discretionary effort in home care work. Work and Occupations, 37,3, 404-432.

- Bush, C.G. (2009) Women and the assessment of technology. In Kaplan, D.M. (ed.) Readings in the Philosophy of Technology. Lanham, MD: Rowman and Littlefield, pp. 121-126.

- Cameron, C. and Moss, P. (2007) Care Work in Europe: Current Understandings and Future Directions. Abingdon: Taylor and Francis.

- Cameron, D. (2009) The age of austerity. Speech at Conservative Party conference, Cheltenham, April. Available online at http://conservativespeeches.sayit.mysociety.org/speech/601367. Last accessed 6 June 2016.

- Carers UK (2012) Growing the Care Market: Turning a Demographic Challenge into an Economic Opportunity. London: Carers UK.

- Carroll, M., Smith, M., Oliver, G., Sung, S. (2009) Recruitment and retention in frontline services: the case of childcare. Human Resource Management Journal, 19,1, 5974.

- Centre for Local Economic Strategies (CLES) (2014) Austerity Uncovered. Report for TUC. Manchester: Centre for Local Economic Strategies.

- Centre for Workforce Intelligence (CFWI) (2013) Horizon-scanning Workforce Briefing. In How Can We Recruit and Retain Enough Domiciliary Care Workers to Meet Future Demand? London: CFWI.

- Clarke, J. and Newman, J. (2012) The alchemy of austerity. Critical Social Policy, 32,3, 299-319.

- Clements, L. (2015) Welsh Social Care Law Risks Taking Us Back 20 Years By Providing Bare Minimum. Community Care, available online at http://www.communitycare.co.uk/2015/01/02/welsh-social-care-law-risks-taking-usback-20-years-providing-bare-minimum/. Last accessed 6 June 2016.

- Cockburn, C. and Ormrod, S. (1993) Gender and Technology in the Making. London: Sage.

- Commission on Public Service Governance and Delivery (2014) Final Report. Cardiff: Welsh Government. Available online at http://gov.wales/docs/dpsp/publications/psgd/140120-psgd-full-report-env2.pdf. Last accessed 6 June 2016.

- Corsetti, G. (2012) Austerity: Too Much of a Good Thing? London: Centre for Economic Policy Research.

- CM2000 (2014) Available online at http://www.cm2000.co.uk/moreforless (last accessed 11 November 2016).

- Department of Health (2016) Care and Support Statutory Guidance, updated 9 May 2016. Available online at https://www.gov.uk/guidance/care-and-support-statutoryguidance. Last accessed 6 June 2016.

- Dilnot Commission (2011) Fairer Care Funding. London: Commission on Funding of Care and Support.

- Duffy, M., Randy, A. and Hammonds, C. (2013) Counting care work: the empirical and policy applications of care theory. Social Problems, 60,2, 145-167. 
- Eaton, S.C. (2000) Beyond 'unloving care': linking human resource management and patient care quality in nursing homes. The International Journal of Human Resource Management, 11,3, 591-616.

- Eborall, C. (2010) The State of the Adult Social Care Workforce in England. London: Skills for Care.

- Edebalk, P.G., Samuelsson, G. and Ingvad, B. (1995) How elderly people rank-order the quality characteristics of home services. Ageing and Society, 15,1, 83-102.

- Equality and Human Rights Commission (EHRC) (2011) Close to Home: an Inquiry into Older People and Human Rights in Homecare. London: Equality and Human Rights Commission.

- England, P. (2005) Emerging theories of care work. Annual Review of Sociology, 31, 381-399.

- England, P. and Folbre, N. (1999) The cost of caring. The Annals of the American Academy of Political and Social Science, 561,1, 39-51.

- England, P., Budig, M. and Folbre, N. (2002) Wages of virtue: the relative pay of care work. Social Problems, 49,4, 455-473.

- Eriksen, T.H. (2001) Tyranny of the Moment: Fast and Slow Time in the Information Age. London: Pluto Press.

- Eustis, N.N. and Fischer, L.R. (1991) Relationships between homecare clients and their workers: implications for the quality of care. The Gerontologist, 31,4, 447-456.

- Evans, A.J. (2012) What is austerity? Economic Affairs, 32,1, 1.

- Fawcett Society (2012) The Impact of Austerity on Women. London: Fawcett Society.

- Fawcett Society (2013) The Changing Labour Market: Delivering for Women, Delivering for Growth. London: Fawcett Society.

- Fenton, W. (2013) Size and Structure of the Adult Social Care Sector and Workforce in England. London: Skills for Care.

- Fernandez, J.-L., Snell, T. and Wistow, G. (2014) Personal Social Services Research Unit Discussion Paper 2867. Personal Social Services Research Unit. In Changes in the Patterns of Social Care Provision in England 2005/6 to 2012/13. London.

- Finlayson, A. (2010) The broken society versus the social recession. Soundings, 44,1, 22-34.

- Francis, J. and Netten, A. (2004) Raising the quality of home care: a study of serviceusers' views. Social Policy and Administration, 38,3, 290-305.

- Gardiner, L. (2014) Zero-hours Contracts: the Latest Figures and Analysis. London: Resolution Foundation.

- Gardiner, L. (2015) The Scale of Minimum Wage Underpayment in Social Care. London: Resolution Foundation.

- Glenn, E.N. (1992) From servitude to service work: historical continuities in the racial division of paid reproductive labor. Signs, 18,1, 1-43.

- Glenn, E.N. (2010) Forced to Care: Coercion and Caregiving in America. Cambridge, MA: Harvard University Press.

- Graham, H. (1991) The concept of caring in feminist research: the case of domestic service. Sociology, 25,1, 61-78.

- Griffin, P. (2015) Crisis, austerity and gendered governance: a feminist perspective. Feminist Review, 109,1, 49-72.

- Gurvitch, G. (1963) The Spectrum of Social Time. Dordrecht: D. Reidel.

- Hansard (2013) Westminster Hall Debate, Home Care Workers, 6 March 2013. Hansard c. 243 WH. 
- Harrington, J. (2012) Time as a dimension of medical law. Medical Law Review, 20,4, 491-515.

- Hasler, F. and Marshall, S. (2013) Think Local Act Personal and Disability Rights UK. In Trust Is the Key: Increasing the Take-up of Direct Payments. London: Disability Rights UK.

- Hayes, L.J.B. (2014) Women's voice and equal pay: judicial regard for the gendering of collective bargaining. In Bogg, A. and Novitz, T. (eds) Voices at Work: Continuity and Change in the Common Law World. Oxford: Oxford University Press, pp. 35-54.

- Hayes, L.J.B. (2015) Care and control: are the national minimum wage entitlements of homecare workers at risk under the Care Act 2014? Industrial Law Journal, 44,4, 492-521.

- Hayes, L.J.B. (2017) Stories of Care, a Labour of Law. Basingstoke: Palgrave Macmillan.

- Himmelweit, S. (2007) The prospects for caring: economic theory and policy analysis. Cambridge Journal of Economics, 31,4, 581-599.

- HM Government (2009) Shaping the future of care together. Department of Health, 14 July 2009, Cm 7673, Available online at https://www.gov.uk/government/publications/shaping-the-future-of-care-together (last accessed 11 November 2016).

- Holmes, J. (2015) An Overview of the UK Domiciliary Care Sector. Wallington: UK Homecare Association.

- House of Commons Scottish Affairs Committee (2014) Zero-hours contracts in Scotland: an interim report. Tenth Report of Session, 2013-2014. HC 654, House of Commons. London: Stationary Office.

- Hussein, S. and Manthorpe, J. (2014) Structural marginalisation among the long-term care workforce in England: evidence from mixed-effect models of national pay data. Ageing and Society, 34,1, 21-41.

- IPC Market Analysis Centre (2012) Where the Heart Is .... A Review of the Older People's Homecare Market in England. Oxford: Oxford Brookes University.

- Jacobs, A. and Padavic, I. (2015) Hours, scheduling and flexibility for women in the US low-wage labour force. Gender. Work and Organization, 22,1, 67-86.

- Kingsmill, D. (2014) Taking Care - an Independent Report into Working Conditions in the Care Sector. London: The Kingsmill Review.

- Kessler-Harris, A. (1982) Out to Work: a History of Wage-earning Women in the US. Oxford: Oxford University Press.

- Koehler, I. (2014) Key to Care. London: Burstow Commission on the Future of the Home Care Workforce.

- Laing, W. (2014) Strategic Commissioning of Long Term Care for Older People. London: Laing Buisson.

- Langan, M. (1990) Community care in the 1990s: the community care white paper: caring for people. Critical Social Policy, 10,29, 58-70.

- Latimer, H. (2013) The straight line: sexuality, futurity and the politics of austerity. English Studies in Canada, 39,4, 21-24.

- Lethbridge, J. (2011) Care Services for Older People in Europe: Challenges for Labour. London: Public Services International Research Unit.

- Levitas, R. (2012) The just's umbrella: austerity and the big society in coalition policy and beyond. Critical Social Policy, 32,3, 320-342.

- Lewis, J. and West, A. (2014) Re-shaping social care services for older people in England: policy development and the problem of achieving 'good care'. Journal of Social Policy, 43,1, 1-18. 
- Lonergan, G. (2015) Migrant women and social reproduction under austerity. Feminist Review, 109,1, 124-145.

- Low Pay Commission (2013) National Minimum Wage Report, Cm 8565. Department for Business, Innovation and Skills. London: Stationary Office.

- Low Pay Commission (2016) Annual Report, March 2016, Cm 8565. Department for Business, Innovation and Skills. London: Stationary Office.

- Mullan, P. (2000) The Imaginary Time Bomb. London: I.B. Taurus.

- Mundlak, G. (2012) The wages of care-workers: from structure to agency. In Fudge, J., McCrystal, S. and Sankaran, K. (eds) Challenging the Legal Boundaries of Work Regulation. Oxford: Hart, pp. 189-212.

- National Audit Office (2014) Adult Social Care in England: Overview. London: Department of Health and Department for Communities.

- National Audit Office (2016) Ensuring Employers Comply with National Minimum Wage Regulations. London: Department for Business, Innovation and Skills / HMRC.

- Needham, C. and Carr, S. (2009) Co-production: an Emerging Evidence Base for Adult Social Care Transformation. London: Research Briefing 31. Social Care Institute for Excellence.

- Novitz, T. and Syrpis, P. (2015) The place of domestic work in Europe. European Labour Law Journal, 6,1, 104-127.

- Nuttin, J. (1985) Future Time Perspective and Motivation: Theory and Research Method. Abingdon: Taylor and Francis.

- Oxfam UK (2013) The True Cost of Austerity and Inequality. London: Oxfam Case Study.

- Palmer, E. and Eveline, J. (2012) Sustaining low pay in aged care work. Gender, Work and Organization, 19,3, 254-275.

- Pearson, R. and Elson, D. (2015) Transcending the impact of the financial crisis in the UK: towards plan F - a feminist economic strategy. Feminist Review, 109,1, 8-30.

- Pennycook, M., Cory, G. and Alakeson, V. (2013) A Matter of Time, the Rise of Zero-hours Contracts. London: Resolution Foundation.

- Pierson, P. (2002) Coping with permanent austerity. In Pierson, P. (ed.) The New Politics of the Welfare State. Oxford: Oxford University Press.

- Potter, L. and Westall, C. (2013) Neoliberal Britain's austerity foodscape: home economics, veg patch capitalism and culinary temporality. New Formations: a Journal of Culture/Theory/Politics, 80-81, 155-178.

- Public Accounts Committee (2014) Adult social care in England. Sixth Report of Session 2014-15. London: Public Accounts Committee.

- Rasmussen, B. (2004) Between endless needs and limited resources: the gendered construction of a greedy organization. Gender, Work and Organization, 11,5, 506525.

- Renaissance Personnel Ltd (2016) Domiciliary Care Manager Spec. Available online at http://www.renaissancepersonnel.co.uk/current-job-oppenings.aspx?id=12. Last accessed 6 June 2016.

- Rubery, J. (2015) Austerity and the future for gender equality in Europe. IRL Review, $68,4,715-741$.

- Rubery, J. and Grimshaw, D. (2007) Undervaluing Women's Work. Manchester: Equal Opportunities Commission.

- Rubery, J., Grimshaw, D. and Hebson, G. (2012) Exploring the limits to local authority social care commissioning: competing pressures, variable practices and unresponsive providers. Public Administration, 91,2, 419-437. 
- Rubery, J., Grimshaw, D., Hebson, G. and Ugarte, S. (2015) It's all about time: time as contested terrain in the management and experience of domiciliary care work in England. Human Resource Management, 54,5, 753-772.

- Rubery, J., Hebson, G., Grimshaw, D., Carroll, M., Smith, S. and Marchington, L. (2011) The Recruitment and Retention of a Care Workforce for Older People. Manchester: Manchester Business School and Department of Health.

- Rubery, J. and Urwin, P. (2011) Bringing the employer back in: why social care needs a standard employment relationship. Human Resource Management Journal, 21,2, 122-137.

- Rubery, J. and Rafferty, A. (2013) Women and recession revisited. Work, Employment and Society, 27,3, 414-432.

- Schües, C. (2011) The power of time: temporal experiences and a-temporal thinking. In Schües, C., Olkowski, D. and Fielding, H. (eds) Time in Feminist Phenomenology. Bloomington, IN: Indiana University Press, 60-78.

- Stoller, S. (2011) Gender and anonymous temporality. In Schües, C., Olkowski, D. and Fielding, H. (eds) Time in Feminist Phenomenology. Bloomington, IN: Indiana University Press, 79-90.

- Stone, R.I. and Weiner, J.M. (2001) Who Will Care For Us? Addressing the Longterm Care Workforce Crisis. Washington, DC: The Urban Institute and AAHSA

- Taylor-Gooby, P. (2009) Political legitimacy and social citizenship: a dilemma of austerity. Paper presented at the Social Policy Association Annual Conference. June: Edinburgh.

- Taylor-Gooby, P., Gumy, J.M. and Otto, A. (2015) Can 'new welfare' address poverty through more and better jobs? Journal of Social Policy, 44,1, 83-104.

- Taylor-Gooby, P. and Stoker, G. (2011) The coalition programme: a new vision for Britain or politics as usual? The Political Quarterly, 82,1, 4-15.

- Theodoropoulou, S. and Watt, A. (2011) Withdrawal Symptoms: an Assessment of the Austerity Packages in Europe. Brussels: ETUI.

- Thornley, C. (2006) Unequal and low pay in the public-sector. Industrial Relations Journal, 37,4, 344-358.

- Triggle, N. (2015) One Million People in Need 'Struggle Alone'. BBC News. Available online at http://www.bbc.co.uk/news/health-34576012 (last accessed 11 November 2016).

- UK Homecare Association (UKHCA) (2010) The Homecare Pledge: a Challenge to National and Local Politicians. Wallington: UK Homecare Association.

- UK Homecare Association (UKHCA) (2012) Care is Not a Commodity. Wallington: UK Homecare Association.

- UK Homecare Association (UKHCA) (2015) A Minimum Price for Homecare. Wallington: UK Homecare Association.

- UNISON (2012) Time to Care: A UNISON Report into Homecare. London: UNISON.

- UNISON (2016) Suffering Alone at Home. London: UNISON. Available online at https://www.unison.org.uk/content/uploads/2016/01/23574_Save_care_now_homecar e_report-5.pdf. Last accessed 6 June 2016.

- Walby, S. (2009) Gender and the Financial Crisis. Available online at http://www.lancaster.ac.uk/fass/doc_library/sociology/Gender_and_financial_crisis_S ylvia_Walby.pdf. Last accessed 6 June 2016.

- Walby, S. (2012) Enquête on the current financial crisis: the UK. European Societies, 14,1, 151-152. 
- Walby, S. (2015) Gender and the crisis: contested transformations of the gender regime. Paper presented at the 'Equal is not Enough' conference, Antwerp, February.

- Wallace, J., Mathias, M. and Brotchie, J. (2013) Weathering the Storm? A Look at Small Countries' Public Services in Times of Austerity. Fife: Carnegie UK Trust and Wales Public Services 2025. Available online at http://www.carnegieuktrust.org.uk/carnegieuktrust/wpcontent/uploads/sites/64/2016/02/pub1455011592.pdf. Last accessed 6 June 2016.

- Weinberg, A.M. (1966) Can technology replace social engineering? In Thompson, W.B. (ed.) Controlling Technology, Contemporary Issues. Buffalo, NY: Prometheus Books, 41-48.

- Welsh Government (2015) Implementation of the Social Services and Well-being (Wales) Act 2014. WG23315. Cardiff: Welsh Government.

- Wittenberg, R., Ho, B., Hancock, R., Morciano, M., Comas-Herrera, C., Mally, J., King, D. (2011) Discussion paper 2811/2. In Projections of Demand for and Costs of Social Care for Older People in England 2010-2030. London: PSSRU, London School of Economics.

- Wynn, M. (2013) Austerity and the crisis in employment rights. In Busby, N., MacDermont, M., Rose, E. and Sales, A. (eds) Access to Justice in Employment Disputes: Surveying the Terrain. London: Institute of Employment Rights, pp. 4-5.

\section{Biographies}

Dr L.J.B. Hayes lectures in discrimination and law, sociology of law and research methods at Cardiff Law School. She holds the Law and Society Research Fellowship 2013-16, from which a key output is her monograph Stories of Care. A Labour of Law. Gender and Class at Work (Palgrave Macmillan, 2017). Her current research examines how new forms of regulation in care work both challenge and extend the traditional boundaries of labour law.

Sian Moore is Professor of Employment Relations and Human Resource Management and Director of the Work and Employment Research Unit (WERU) at the University of Greenwich. Her research centres on the relationship between gender and class, consciousness and activism. She has also published on statutory trade union recognition and trade union learning, equality reps and the British Airways dispute 2009-11. 